K A N D A I

\begin{tabular}{|l|l|l|}
\hline Volume 17 & No. 1, Mei 2021 & Halaman 14-29 \\
\hline
\end{tabular}

\title{
SIKAP MAHASISWA PULAU BANGKA TERHADAP BAHASA INDONESIA, BAHASA DAERAH, DAN BAHASA ASING \\ (Attitude of Bangka Island Students towards Indonesian, Local Language, and Foreign Language)
}

\author{
Prima Hariyanto \\ Kantor Bahasa Provinsi Kepulauan Bangka Belitung \\ Kompleks Perkantoran dan Permukiman Terpadu Pemerintah Provinsi \\ Jalan Pulau Bangka, Airitam, Pangkalpinang, Indonesia \\ Pos-el: prima.hariyanto@kemdikbud.go.id
}

(Diterima: 30 April 2020; Direvisi: 7 Oktober 2020; Disetujui: 23 Februari 2021)

\begin{abstract}
Indonesian must continue to be fostered and developed to become a modern language for a communication language in various aspects of life and fields of science. To realm this aim must be supported by Indonesian speakers who have a positive attitude towards Indonesian. Therefore, this study aims to determine the attitude of students in Bangka island towards Indonesian, local language, and foreign language associated with the results of the Indonesian Language Proficiency Test (UKBI). This research is a quantitative study using instruments of questionnaires with Likert scale models and Trustone models. The research respondents are 386 students from eight universities in Bangka Island. Based on the analysis, it is concluded that Bangka Island students are more likely to be positive about Indonesian. The same is true of students' motivation towards Indonesian. Although there are negative attitudes, the numbers are not too alarming. The study also found out that in the younger generation group, the higher their age, the more negative their attitude and language motivation. Conversely, the younger their age, the more positive their attitude and language motivation. Another finding from this study is the more positive a person's attitude towards Indonesian, the higher the UKBI score.
\end{abstract}

Keywords: language attitude, learning motivation, Indonesian Language Proficiency Test

\begin{abstract}
Abstrak
Bahasa Indonesia harus terus dibina dan dikembangkan agar menjadi bahasa modern untuk bahasa komunikasi dalam berbagai sendi kehidupan dan ranah keilmuan. Untuk mencapai cita-cita tersebut harus didukung oleh penuturnya yang memiliki sikap positif terhadap bahasa Indonesia. Oleh sebab itu, penelitian ini bertujuan mengetahui sikap mahasiswa di Pulau Bangka terhadap bahasa Indonesia, bahasa daerah, dan bahasa asing yang dikaitkan dengan hasil Uji Kemahiran Berbahasa Indonesia (UKBI). Penelitian ini merupakan penelitian kuantitatif dengan menggunakan instrumen kuisioner model skala Likert dan model Trustone. Responden penelitian ini adalah 386 mahasiswa dari delapan perguruan tinggi di Pulau Bangka. Berdasarkan hasil analisis disimpulkan bahwa mahasiswa Pulau Bangka lebih cenderung bersikap positif terhadap bahasa Indonesia. Begitu pula dengan motivasi belajar mahasiswa terhadap bahasa Indonesia. Meskipun ada yang bersikap negatif, jumlahnya tidak terlalu mengkhawatirkan. Penelitian ini juga menemukan bahwa pada kelompok generasi muda, semakin tinggi usia generasi muda semakin negatif sikap bahasa dan motivasi mereka. Sebaliknya, semakin muda usia generasi muda, semakin positif sikap bahasa dan motivasi mereka. Temuan lain dari penelitian ini adalah semakin positif sikap seseorang terhadap bahasa Indonesia, semakin tinggi pula nilai UKBI-nya.
\end{abstract}

Kata-kata kunci: sikap bahasa, motivasi belajar, Uji Kemahiran Berbahasa Indonesia 


\section{PENDAHULUAN}

Bahasa Indonesia memiliki peranan penting bagi bangsa dan negara Indonesia. Sebagai bahasa nasional dan resmi negara, bahasa Indonesia seharusnya digunakan dalam semua ranah resmi di negara ini. Oleh sebab itu, bahasa Indonesia harus terus dibina dan dikembangkan agar menjadi bahasa modern untuk bahasa komunikasi dalam berbagai sendi kehidupan dan berbagai ranah keilmuan. Selain itu, salah satu cita-cita besar bangsa ini adalah menjadikan bahasa Indonesia sebagai penghela ilmu pengetahuan dan dapat menjadi bahasa internasional yang disegani di dunia.

Jika dilihat berdasarkan kriteria penilaian (Garvin \& Mathiot, 1968), bahasa Indonesia hanya memiliki dua dari tiga kriteria penilaian yang dapat diterapkan pada bahasa standar, yaitu penilaian berdasarkan ciri khuluk (intrinsic properties) yang ditandai dengan sifat stabil dan fleksibel bahasa tersebut dan kemampuan bahasa tersebut untuk menggambarkan sesuatu yang abstrak dengan tepat dan jelas, penilaian serta sikap penutur terhadapnya, dan penilaian berdasarkan kemampuan bahasa itu mempersatukan para penutur yang berasal dari dialek yang berbedabeda ke dalam suatu masyarakat tutur yang mempunyai identitas berbeda dari masyarakat tutur yang lain. Kriteria penilaian serta sikap penutur terhadapnya belum dimiliki oleh bahasa Indonesia. Bahasa Indonesia masih berhadapan dengan kecenderungan sikap penuturnya yang belum menunjukkan loyalitas terhadap bahasa Indonesia.
Cita-cita besar bangsa ini terhadap bahasa Indonesia harus didukung oleh sikap positif penuturnya terhadap bahasa Indonesia. Sikap bahasa adalah peristiwa kejiwaan yang dapat diamati melalui perilaku berbahasa dan perilaku tutur. Jika dikaitkan dengan pendapat Saussure (Saussure, 1966) yang membedakan langue dan parole, sikap bahasa adalah sistem atau langue, sedangkan perilaku tutur adalah pemakaian kongkret terhadap bahasa atau parole (Sukyadi, 2013).

Generasi muda, khususnya mahasiswa sebagai salah satu masyarakat pengguna bahasa seharusnya memiliki kebanggaan dalam menggunakan bahasa Indonesia dalam komunikasi sehari-hari. Namun, pada kenyataannya mahasiswa belum sepenuhnya memiliki kebanggaan terhadap bahasa Indonesia. Sikap positif terhadap bahasa Indonesia masih kurang. Belum ada rasa bangga, setia, dan keinginan untuk memelihara bahasa Indonesia (Werdiningsih, 2016).

Banyak hal memengaruhi sikap mahasiswa terhadap bahasa Indonesia. Salah satunya adalah kecenderungan merasa lebih percaya diri menggunakan bahasa asing daripada memakai bahasa Indonesia. Kecenderungan ini dapat dilihat pada percakapan para mahasiswa sehari-hari. Mereka akan merasa lebih keren saat berbicara, menulis, atau menyelipkan kata atau istilah dalam bahasa Inggris.

Kebanggaan mahasiswa terhadap bahasa daerah juga tidak kalah memilukan. Kepulauan Bangka Belitung memiliki bahasa daerah varian bahasa Melayu, yakni Melayu Bangka dan Melayu Belitung. Akan tetapi, generasi 
muda, khususnya mahasiswa kurang bangga terhadap bahasa daerahnya sendiri. Namun, penggunaan Bahasa daerah oleh pengguna dari kalangan generasi muda masih mendominasi, terutama di luar wilayah perkotaan Provinsi Kepulauan Bangka Belitung. Kenyataan ini seharusnya dipertahankan, bahkan ditingkatkan agar bahasa daerah tetap lestari.

Di sisi lain, pembelajaran bahasa Indonesia di perguruan tinggi masih dianggap sepele. Mata kuliah Bahasa Indonesia kadang dijalani hanya karena mata kuliah ini merupakan mata kuliah wajib. Mau tidak mau, mahasiswa harus belajar agar lulus di mata kuliah ini. Kesadaran dari diri sendiri untuk belajar bahasa Indonesia masih rendah.

Sikap meremehkan mata kuliah ini muncul karena bahasa Indonesia dianggap sudah biasa digunakan dalam kehidupan sehari-hari sehingga tidak penting lagi dipelajari secara formal. Padahal, apa yang digunakan sehari-hari tentu berbeda dengan apa yang dipelajari di kelas. Mata kuliah Bahasa Indonesia mengajarkan ragam bahasa formal, sedangkan yang digunakan sehari-hari ragam nonformal. Mirisnya, ragam nonformal ini justru terbawa saat mahasiswa berada dalam situasi yang mengharuskan menggunakan ragam formal, misalnya saat presentasi atau menulis laporan akhir.

Penelitian maupun pengkajian tentang sikap bahasa, khususnya sikap bahasa mahasiswa, telah banyak dilakukan oleh Mansyur (2018), Gunarwan (1983), Suhardi (1996), Mukhamdanah (2007), Sobara dan Ardiyani (2013), dan Andarwulan dan Aswadi (2018). Mansyur melakukan kajian sikap bahasa dan pembelajaran bahasa di perguruan tinggi (Mansyur, 2018). Berdasarkan hasil analisis disimpulkan bahwa kebiasaan menggunakan bahasa Indonesia dengan baik dan benar akan meningkatkan prestasi akademik mahasiswa. Selain itu, pemahaman bahasa Indonesia sesuai dengan kaidah bahasa yang baik dan benar diperlukan mahasiswa agar memiliki sikap positif terhadap bahasa Indonesia.

Gunarwan, berdasarkan hasil penelitiannya, melihat adanya sikap positif kalangan mahasiswa terhadap bahasa Indonesia baku. Sikap positif mahasiswa ini dapat berpengaruh baik terhadap sikap masyarakat terhadap penggunaan bahasa Indonesia baku (Gunarwan, 1983).

Suhardi meneliti sikap bahasa mahasiswa dan sarjana dalam pemakaian bahasa sehari-hari mereka di Jakarta. Dari 326 responden disimpulkan bahwa pemakaian bahasa sehari-hari mereka banyak ditentukan oleh bahasa ibu mereka sehari-hari. Mereka yang berbahasa ibu bahasa Indonesia menggunakan bahasa Indonesia, baik di rumah maupun di sekolah atau di tempat bekerja. Sementara itu, alih kode yang digunakan di kalangan mereka hanyalah pada pemakaian bahasa resmi dan ragam tidak resmi (Suhardi, 1996).

Mukhamdanah meneliti pemertahanan dan sikap bahasa di kalangan mahasiswa warga negara Indonesia keturunan Cina di Medan. Hasil penelitian menunjukkan bahwa di dalam ranah keluarga, responden perempuan cenderung lebih banyak menggunakan bahasa Hokkian dengan siapa pun yang diajak bicara. Sementara itu, responden laki-laki cenderung selalu menggunakan bahasa Hokkian pada ranah ketetanggaan, ranah kekariban, ranah transaksi, ranah agama, dan ranah pendidikan juga menunjukkan kecenderungan yang sama (Mukhamdanah, 2007).

Sobara dan Ardiyani meneliti sikap bahasa mahasiswa laki-laki dan perempuan di Jurusan Sastra Jerman 
Universitas Negeri Malang berdasarkan tiga ciri, yaitu kesetiaan bahasa, kebanggaan bahasa, dan kesadaran adanya norma bahasa. Hasil penelitian dengan sampel 20 mahasiwa ini menunjukkan bahwa mahasiswa perempuan mempunyai kebanggaan lebih besar daripada mahasiswa laki-laki. Selain itu, mahasiswa perempuan lebih berhati-hati dalam memilih kata yang tepat. Namun, mahasiswa laki-laki lebih percaya diri dan berbicara lebih lugas dibandingkan mahasiswa perempuan (Sobara \& Ardiyani, 2013).

Andarwulan dan Aswadi meneliti sikap bahasa mahasiswa Universitas Brawijaya. Sampel penelitian adalah 60 mahasiswa bidang ilmu eksak dan sosial. Hasil penelitian menunjukkan bahwa tidak semua mahasiswa memiliki sikap positif terhadap bahasa Indonesia. Kesadaran bahwa bahasa sebagai bagian dari identitas perlu ditingkatkan dalam menciptakan sikap positif yang mengacu pada daya tarik bahasa dan kebanggaan sebagai penutur bahasa (Andarwulan \& Aswadi, 2018).

Dari beberapa penelitian sebelumnya tersebut, penulis bermaksud membuat penelitian serupa, tetapi penelitian ini lebih komprehensif. Penelitian ini melibatkan responden dari beberapa perguruan tinggi di Pulau Bangka, yakni sebanyak 386 responden. Penelitian ini mengukur sikap responden terhadap tiga bahasa, yakni bahasa Indonesia, bahasa daerah, dan bahasa asing. Selain itu, penelitian ini juga menghubungkan sikap bahasa dengan nilai UKBI responden.

Umumnya kompetensi kebahasaan memiliki korelasi dengan sikap bahasa penuturnya. Hipotesis inilah yang ingin dibuktikan dalam kaitannya dengan nilai UKBI dan sikap mahasiswa terhadap bahasanya. Tulisan ini mengkaji korelasi sikap bahasa dan nilai UKBI mahasiswa di Pulau Bangka.
Berdasarkan permasalahan di atas, penelitian ini hanya membatasi masalah pada sikap mahasiswa di Pulau Bangka terhadap bahasa Indonesia, bahasa daerah, dan bahasa asing yang dikaitkan dengan hasil Uji Kemahiran Berbahasa Indonesia (UKBI). Pada umumnya, nilai UKBI berbanding lurus dengan skor sikap Bahasa seseorang yang akan dibuktikan dalam penelitian ini. Tujuan penelitian ini adalah untuk mengetahui (1) seberapa positifkah sikap mahasiswa Pulau Bangka terhadap bahasa Indonesia, bahasa daerah, dan bahasa asing; (2) seberapa positifkah motivasi belajar mahasiswa di Pulau Bangka terhadap mata kuliah Bahasa Indonesia; (3) adakah hubungan antara sikap bahasa dan hasil UKBI; (4) karakteristik apa saja yang berkorelasi dengan sikap bahasa dan hasil UKBI; (5) dan bagaimana gambaran sikap bahasa dan motivasi mahasiswa Pulau Bangka.

\section{LANDASAN TEORI}

Kamus Besar Bahasa Indonesia mengartikan sikap sebagai bentuk tubuh, cara berdiri, perbuatan (dan sebagainya) yang berdasarkan pada pendirian/ keyakinan, perilaku, atau gerak-gerik (Penyusun, 2018). Sikap merupakan fenomena kejiwaan yang umumnya termanifestasi dalam bentuk tindakan atau perilaku sehingga tidak dapat diamati secara langsung, tetapi melalui perilaku. Menurut Rokeach, sikap bukan sesuatu yang bersifat sesaat, melainkan berlangsung dalam jangka waktu relatif lama. Sikap adalah jaringan keyakinan (kognisi) dan nilai yang membuat seseorang berbuat atau bereaksi terhadap suatu objek dengan cara tertentu yang disenanginya (Sumarsono \& Partana, 2002).

Menurut Lambert, sikap terdiri atas tiga komponen, yaitu kognitif, afektif, dan konatif. Kognitif 
berhubungan dengan pengetahuan mengenai alam sekitar dan gagasan yang biasanya masuk dalam kategori proses berpikir. Komponen afektif menyangkut masalah penilaian baik atau tidak baik, suka atau tidak suka terhadap sesuatu atau suatu keadaan. Komponen konatif menyangkut perilaku atau perbuatan sebagai putusan akhir kesiapan reaktif terhadap suatu keadaan (Chaer \& Agustina, 2010).

Melalui ketiga komponen inilah peneliti dapat menduga bagaimana sikap seseorang terhadap sesuatu atau keadaan yang dihadapinya. Jika ketiganya sejalan, dapat dikatakan bahwa perilakunya menunjukkan sikap. Sebaliknya, jika tidak sejalan, perilakunya tidak menunjukkan sikap. Setiap sikap terdiri atas tiga komponen, yaitu kepercayaan/keyakinan, penilaian suka atautidak suka, dan kecenderungan perilaku.

Sikap merupakan pradisposisi yang dipelajari, tidak diwariskan, dan cenderung relatif stabil. Selain itu, sikap mempunyai kecenderungan untuk bertahan, tetapi sangat dipengaruhi oleh pengalaman. Bentuk sikap bervariasi menurut rasa suka atau tidak suka. Sikap juga merupakan konstruksi yang kompleks karena sikap ada yang positif dan ada pula yang negatif terhadap objek (Sugiyono \& Sasangka, 2011).

Menurut Anderson, sikap terbagi atas sikap kebahasaan dan nonkebahasaan, seperti sikap sosial, sikap politik, sikap estetis, dan sikap keagamaan. Kedua jenis sikap ini dapat menyangkut keyakinan atau kognisi mengenai bahasa. Menurutnya, sikap bahasa adalah tata keyakinan atau kognisi yang relatif berjangka panjang, sebagian mengenai bahasa atau objek bahasa yang memberikan kecenderungan seseorang untuk bereaksi dengan cara tertentu yang disenanginya. Akan tetapi, sikap tersebut dapat berupa sikap positif atau negatif. Sikap negatif terhadap bahasa dapat terjadi bila orang atau sekelompok orang tidak mempunyai lagi rasa bangga terhadap bahasanya dan mengalihkannya ke bahasa lain yang bukan miliknya. Hal tersebut dapat dipengaruhi faktor politis, etnis, ras, gengsi, anggapan bahasanya terlalu rumit, dan sebagainya (Chaer \& Agustina, 2010).

Sikap kebahasaan merupakan hal penting berkaitan dengan suatu bahasa karena sikap bahasa dapat melangsungkan hidup suatu bahasa. Pada dasarnya bahasa bersifat dinamis sebab masyarakat penutur bahasa selalu berubah dan berkembang. Bahasa sebagai bentuk tingkah laku verbal manusia menjadi salah satu aspek dari seluruh tingkah laku manusia dalam berkomunikasi.

Selain itu, sikap bahasa merupakan posisi mental atau perasaan terhadap bahasa sendiri atau bahasa orang lain (Kridalaksana, 2001). Sikap positif terhadap bahasa dapat dilihat dari kebanggaan terhadap bahasa sendiri. Bersikap positif terhadap bahasa berarti menerima bahasanya dengan segala kelebihan dan kekurangannya secara terbuka tanpa merasa kurang percaya diri jika dibandingkan bahasanya dengan bahasa lain.

Menurut Pateda, sikap positif ditunjukkan melalui perilaku yang mencerminkan rasa tanggung jawab, rasa memiliki, sikap menghormati, dan kemauan membina dan mengembangkan bahasanya. Sikap tersebut ditandai perilaku: (1) selalu berhati-hati menggunakan bahasa tersebut; (2) tidak merasa senang melihat orang memakai bahasanya secara serampangan; (3) memperingatkan dan mengoreksi pemakai bahasa lain jika membuat kekeliruan; (4) tertarik pada penjelasan tentang bahasanya; (5) berusaha menambah pengetahuan tentang 
bahasanya; (6) bertanya kepada ahli jika menemui masalah dalam bahasanya (Pateda, 1987).

Manifestasi terhadap uraian sikap di atas diolah sedemikian rupa sehingga menjadi pernyataan-pernyataan di dalam kuisioner. Harapannya, kuisioner penelitian ini dapat menggambarkan secara jelas bagaimana sikap dan perilaku mahasiswa terhadap bahasanya, baik bahasa Indonesia, bahasa daerah, maupun bahasa asing.

\section{METODE PENELITIAN}

Penelitian ini merupakan penelitian kuantitatif yang mengaitkan ciri sosial responden, nilai UKBI, dan justifikasinya terhadap sejumlah parameter sikap bahasa dan motivasi belajar bahasa. Data penelitian ini adalah tanggapan responden dalam menyikapi kondisi kebahasaan dalam kehidupan sehari-harinya. Data diperoleh dengan cara meminta responden mengisi kuisioner penelitian ini. Data dikumpulkan sebelum responden mengikuti UKBI.

Sikap dan motivasi responden yang terimplikasi dalam kuisioner diasumsikan berkorelasi positif dengan nilai UKBI. Parameter untuk mengukur sikap dan motivasi adalah kemampuan, kebanggaan, penggunaan, dan kemanfaatan. Sikap seseorang terhadap sebuah bahasa dinyatakan baik apabila orang itu memiliki derajat kemampuan, kebanggaan, penggunaan, dan pemanfaatan yang baik.

Instrumen yang digunakan dalam penelitian ini adalah kuisioner dengan model skala Likert dan model Trustone. Skala Likert ini dikenal dengan metode summated ratting yang dikembangkan pada tahun 1932. Skala Likert berisi seperangkat pernyataan yang harus ditanggapi oleh responden. Pernyataanpernyataan tersebut diharapkan dapat menggiring kecenderungan mahasiswa sehingga dapat menampakkan sikap berbahasanya apakah positif atau negatif.

Penskoran setiap jenis respons pada setiap pernyataan akan mendapat bobot nilai sesuai dengan arah pernyataannya. Sistem penskoran untuk pernyataan positif adalah bobot 5 untuk jawaban responden sangat setuju; 4 untuk jawaban setuju; 3 untuk jawaban ragu; 2 untuk jawaban tidak setuju; dan 1 untuk jawaban sangat tidak setuju. Penskoran pernyataan negatif merupakan kebalikan dari penskoran pernyataan positif, yakni bobot 1 untuk jawaban sangat setuju, 2 untuk jawaban setuju, 3 untuk jawaban ragu, 4 untuk jawaban tidak setuju, dan 5 untuk jawaban sangat tidak setuju.

\section{PEMBAHASAN}

\section{Populasi dan Karakteristik Responden}

Responden penelitian ini berjumlah 386 orang, tetapi kuisioner yang dapat diolah sebanyak 375 buah. Sebanyak 11 kuisioner tidak dapat diolah lebih lanjut karena tidak diisi secara lengkap atau terdapat tanggapan jawaban yang tidak konsisten terhadap pernyataan yang disajikan dalam pernyataan positif dan negatif. Responden adalah mahasiswa STKIP Muhammadiyah Bangka Belitung, Universitas Bangka Belitung, IAIN Syekh Abdurrahman Siddik Bangka Belitung, Universitas Terbuka, AMIK Atma Luhur, STIH Pertiba, STIE Ibek, dan STIH Ibek.Komposisi responden berdasarkan jenis kelamin dapat dikatakan tidak cukup berimbang, yakni 148 responden laki-laki atau sekitar $39.47 \%$ dan 227 responden perempuan atau sekitar 60,53\%. Rata-rata usia responden adalah 21,15 tahun dengan komposisi responden berkisar antara 18 
sampai dengan 50 tahun. Komposisi responden atas kedua karakteristik tersebut adalah sebagai berikut.

Tabel 1

Komposisi Responden

Usia dan Jenis Kelamin

\begin{tabular}{|c|c|c|c|}
\hline \multirow{2}{*}{$\begin{array}{c}\text { Usia } \\
\text { (Tahun) }\end{array}$} & \multicolumn{2}{|c|}{ Jenis Kelamin } & \multirow[b]{2}{*}{$\underset{\mathbf{h}}{\text { Jumla }}$} \\
\hline & $\begin{array}{l}\text { Laki- } \\
\text { Laki }\end{array}$ & Perempuan & \\
\hline 18 & 2 & 12 & 14 \\
\hline 19 & 14 & 22 & 36 \\
\hline 20 & 22 & 73 & 95 \\
\hline 21 & 44 & 77 & 121 \\
\hline 22 & 36 & 34 & 70 \\
\hline 23 & 12 & 4 & 16 \\
\hline$\geq 24$ & 18 & 5 & 23 \\
\hline Total & 148 & 227 & 375 \\
\hline
\end{tabular}

Berdasarkan Tabel 1 dapat dilihat bahwa jumlah reponden perempuan lebih banyak daripada responden lakilaki pada kelompok usia yang lebih rendah (19-21 tahun). Namun, pada kelompok usia yang lebih tinggi (22 tahun ke atas), jumlah responden lakilaki lebih banyak daripada responden perempuan. Komposisi responden ini juga dapat menggambarkan komposisi jenis kelamin mahasiswa. Secara keseluruhan jumlah mahasiswa perempuan lebih banyak daripada mahasiswa laki-laki. Akan tetapi, data tersebut juga menunjukkan bahwa semakin tinggi usianya, justru semakin banyak jumlah mahasiswa laki-laki dan semakin sedikit jumlah mahasiswa perempuan.

Penggunaan bahasa di rumah dapat terlihat pada tabel 2 sebagai berikut.

Tabel 2

Komposisi Responden Jenis Kelamin dan Bahasa di Rumah

\begin{tabular}{|c|c|c|c|}
\hline \multirow{2}{*}{$\begin{array}{c}\text { Bahasa di } \\
\text { Rumah }\end{array}$} & \multicolumn{2}{|c|}{ Jenis Kelamin } & \multirow[b]{2}{*}{ Jumlah } \\
\hline & $\begin{array}{l}\text { Laki- } \\
\text { Laki }\end{array}$ & $\begin{array}{c}\text { Perempu } \\
\text { an }\end{array}$ & \\
\hline $\begin{array}{l}\text { Bahasa } \\
\text { Melayu }\end{array}$ & 70 & 135 & 205 \\
\hline $\begin{array}{l}\text { Bahasa } \\
\text { Indonesia }\end{array}$ & 67 & 85 & 152 \\
\hline Bahasa & 11 & 7 & 18 \\
\hline
\end{tabular}

\begin{tabular}{c|c|c|c}
\hline Lainnya & & & \\
\hline Total & 148 & 227 & 375 \\
\hline
\end{tabular}

Berdasarkan Tabel 2, dapat diketahui bahwa penggunaan bahasa Melayu di rumah lebih dominan dibandingkan penggunaan bahasa Indonesia ataupun bahasa lainnya di rumah. Temuan ini cukup menggembirakan mengingat bahasa Melayu, khususnya Melayu Bangka, belum diajarkan secara formal di sekolah.

Sistem pendidikan di Provinsi Kepulauan Bangka Belitung belum memasukkan mata pelajaran bahasa Melayu Bangka ke dalam muatan lokal di sekolah. Oleh karena itu, diharapkan usaha pelestarian bahasa Melayu Bangka dapat dilaksanakan di rumah dan lingkungannya sehingga semakin banyak keluarga yang mengajarkan atau menggunakan bahasa Melayu Bangka di rumah dan lingkungan sekitar. Upaya pelestarian di lingkungan keluarga ini penting mengingat bahasa daerah adalah salah satu warisan kebudayaan bangsa yang harus selalu kita jaga dan pelihara kelestariannya.

Penggunaan bahasa di luar kelas dalam kampus dapat terlihat pada tabel 3 sebagai berikut.

Tabel 3

Komposisi Responden

Jenis Kelamin dan Bahasa di Luar Kelas, Lingkungan Kampus

\begin{tabular}{|c|c|c|c|}
\hline \multirow{2}{*}{$\begin{array}{c}\text { Bahasa di } \\
\text { Kampus }\end{array}$} & \multicolumn{2}{|c|}{ Jenis Kelamin } & \multirow[b]{2}{*}{ Jumlah } \\
\hline & $\begin{array}{l}\text { Laki- } \\
\text { Laki }\end{array}$ & $\begin{array}{c}\text { Peremp } \\
\text { uan }\end{array}$ & \\
\hline $\begin{array}{l}\text { Bahasa } \\
\text { Melayu }\end{array}$ & 75 & 108 & 183 \\
\hline $\begin{array}{l}\text { Bahasa } \\
\text { Indonesia }\end{array}$ & 73 & 119 & 192 \\
\hline Total & 148 & 227 & 375 \\
\hline
\end{tabular}

Berdasarkan Tabel 3 dapat diketahui bahwa penggunaan bahasa Melayu dan bahasa Indonesia di luar 
kelas dalam lingkungan kampus berimbang. Jumlah responden yang menggunakan bahasa Indonesia kurang lebih sama banyaknya dengan yang menggunakan bahasa Melayu di luar kelas.

Temuan ini menunjukkan bahwa mahasiswa di Pulau Bangka belum terlalu heterogen. Mahasiswa dari luar provinsi belum terlalu banyak sehingga di lingkungan kampus mahasiswa masih dengan mudahnya berbahasa Melayu Bangka. Kenyataan ini mungkin akan berbeda jika jumlah mahasiswa dari luar provinsi sudah cukup banyak. Mahasiswa akan lebih banyak menggunakan bahasa Indonesia agar lawan bicaranya dapat memahami apa yang disampaikan.

\section{Kepositifan Sikap Bahasa Mahasiswa dan Motivasi Belajar Bahasa}

Sebagaimana dijelaskan di subbagian sebelumnya, instrumen yang digunakan adalah kuisioner dengan model skala Likert. Berdasarkan pedoman penskoran dihasilkan rentang nilai sikap yang sangat positif hingga yang sangat negatif dengan perincian sebagai berikut.

Tabel 4

Rentang Nilai

Sikap Bahasa dan Motivasi Mahasiswa

\begin{tabular}{l|c|c|c}
\hline \multirow{2}{*}{ Sikap } & \multicolumn{3}{|c}{ Rentang Nilai } \\
\cline { 2 - 4 } & Sikap & Motivasi & Jumlah \\
\hline $\begin{array}{l}\text { Sangat } \\
\text { Positif }\end{array}$ & $169-210$ & $101-125$ & $269-335$ \\
\hline Positif & $127-168$ & $76-100$ & $202-268$ \\
\hline $\begin{array}{l}\text { Cukup } \\
\text { Negatif }\end{array}$ & $85-126$ & $51-75$ & $135-201$ \\
\hline Negatif & $43-84$ & $26-50$ & $68-134$ \\
\hline $\begin{array}{l}\text { Sangat } \\
\text { Negatif }\end{array}$ & $0-42$ & $0-25$ & $0-67$ \\
\hline
\end{tabular}

Penentuan rentang di setiap tingkat sikap dihasilkan dari akumulasi skor pilihan jawaban (sangat setuju, setuju, ragu-ragu, tidak setuju, dan sangat tidak setuju). Sebagaimana telah dijelaskan pada bagian sebelumnya, pilihan jawaban tersebut memiliki bobot yang berbeda. Untuk pertanyaan positif, skornya secara berurut adalah 5, 4, 3, 2, dan 1 . Untuk pertanyaan negatif, skor secara berurut adalah 1, 2, 3, 4, dan 5 . Akumulasi skor pilihan jawaban tersebut diolah sedemikian rupa sehingga dihasilkan rentang nilai seperti dalam Tabel 4.

Selanjutnya, rentang nilai dalam Tabel 4 digunakan untuk mengategorikan dan menganalisis karekteristik lain semua responden. Berdasarkan penghitungan jumlah nilai dan jumlah responden, rata-rata nilainya adalah 283,37 dengan rata-rata nilai sikap adalah 176,46 dan rata-rata nilai motivasi adalah 106,92. Nilai terendah adalah 201 dan nilai tertinggi adalah 327. Nilai sikap terendah adalah 188 dan nilai sikap tertinggi adalah 206. Nilai motivasi terendah adalah 77 dan nilai tertinggi adalah 136.

Berdasarkan rata-rata nilai, 192 responden $(51,2 \%)$ berada di bawah ratarata dan 183 responden $(48,8 \%)$ di atas rata-rata. Berdasarkan rata-rata nilai sikap, 188 responden $(50,13 \%)$ berada di bawah rata-rata dan 187 responden $(49,87 \%)$ di atas rata-rata. Berdasarkan rata-rata nilai motivasi, 176 responden berada $(46,93 \%)$ di bawah rata-rata dan 199 responden $(53,07 \%)$ di atas rata-rata.

Berdasarkan data tersebut, nilai keseluruhan dan nilai sikap tidak terlalu menunjukkan ketimpangan, yakni 2,4\% dan $0,27 \%$. Berbeda dengan nilai motivasi yang perbedaan jumlah responden di atas dan di bawah rata-rata cukup timpang, yakni $6,13 \%$. Temuan ini menunjukkan bahwa motivasi belajar mahasiswa terhadap bahasa Indonesia belum merata. Beberapa responden mempunyai semangat belajar bahasa Indonesia yang tinggi, tetapi ada pula 
Kandai Vol. 17, No. 1, Mei 2021; 14-29

responden yang semangat belajar bahasa Indonesianya rendah. 


\section{Sikap Bahasa Menurut Jenis Kelamin}

Berdasarkan jenis kelamin, nilai rata-rata sikap mahasiswa laki-laki lebih tinggi daripada nilai rata-rata mahasiswa perempuan. Namun, nilai rata-rata motivasi mahasiswa perempuan lebih tinggi daripada nilai rata-rata mahasiswa laki-laki. Paparan lebih terperinci dapat dilihat dalam Tabel 5 berikut ini.

Tabel 5

Rata-Rata Nilai

Berdasarkan Jenis Kelamin

\begin{tabular}{c|c|c|c}
\hline \multirow{2}{*}{$\begin{array}{c}\text { Jenis } \\
\text { Kelamin }\end{array}$} & \multicolumn{3}{|c}{ Rata-Rata Nilai } \\
\cline { 2 - 4 } & Sikap & Motivasi & Semua \\
\hline Laki-Laki & 176,89 & 106,32 & 283,21 \\
\hline Perempuan & 176,18 & 107,16 & 283,34 \\
\hline
\end{tabular}

Berdasarkan tabel 5 diketahui bahwa secara keseluruhan, nilai rata-rata sikap dan motivasi perempuan lebih tinggi daripada nilai rata-rata laki-laki.

Sementara itu, tabel 6 menyajikan data sikap, motivasi, dan jenis kelamin dengan lengkap.

Tabel 6

Jumlah Responden Berdasarkan Sikap, Motivasi, dan Jenis Kelamin

\begin{tabular}{|c|c|c|c|c|c|c|}
\hline \multirow{2}{*}{ Semua } & \multicolumn{2}{|c|}{$\begin{array}{c}\text { Laki- } \\
\text { Laki }\end{array}$} & \multicolumn{2}{c|}{$\begin{array}{c}\text { Perempua } \\
\text { n }\end{array}$} & \multicolumn{2}{|c|}{ Jumlah } \\
\cline { 2 - 7 } & $\boldsymbol{\Sigma}$ & $\mathbf{\%}$ & $\boldsymbol{\Sigma}$ & $\mathbf{\%}$ & $\boldsymbol{\Sigma}$ & $\%$ \\
\hline $\begin{array}{c}\text { Sangat } \\
\text { Positif }\end{array}$ & 117 & 79,1 & 180 & 79,3 & 297 & 79,2 \\
\hline Positif & 31 & 20,2 & 47 & 20,7 & 77 & 20,5 \\
\hline $\begin{array}{c}\text { Cukup } \\
\text { Negatif }\end{array}$ & 1 & 0,7 & 0 & 0 & 1 & 0,3 \\
\hline
\end{tabular}

\begin{tabular}{|c|c|c|c|c|c|c|}
\hline \multirow[t]{2}{*}{ Sikap } & \multicolumn{2}{|c|}{$\begin{array}{c}\text { Laki- } \\
\text { Laki }\end{array}$} & \multicolumn{2}{|c|}{$\begin{array}{c}\text { Perempua } \\
\text { n }\end{array}$} & \multicolumn{2}{|c|}{ Jumlah } \\
\hline & $\Sigma$ & $\%$ & $\Sigma$ & $\%$ & $\Sigma$ & $\%$ \\
\hline $\begin{array}{l}\text { Sangat } \\
\text { Positif }\end{array}$ & 113 & 76,2 & 117 & 77,9 & 290 & 77,3 \\
\hline Positif & 35 & 22,1 & 50 & 22,1 & 84 & 22,4 \\
\hline $\begin{array}{l}\text { Cukup } \\
\text { Negatif }\end{array}$ & 1 & 0,7 & 0 & 0 & 1 & 0,3 \\
\hline \multirow{2}{*}{$\begin{array}{c}\text { Motiva } \\
\text { si }\end{array}$} & \multicolumn{2}{|c|}{$\begin{array}{c}\text { Laki- } \\
\text { Laki }\end{array}$} & \multicolumn{2}{|c|}{$\begin{array}{c}\text { Perempua } \\
\text { n }\end{array}$} & \multicolumn{2}{|c|}{ Jumlah } \\
\hline & $\Sigma$ & $\%$ & $\Sigma$ & $\%$ & $\Sigma$ & $\%$ \\
\hline Sangat & 114 & 77,1 & 172 & 75,7 & 286 & 76,3 \\
\hline
\end{tabular}

\begin{tabular}{|l|l|l|l|l|l|l|}
\hline Positif & & & & & & \\
\hline Positif & 34 & 22,9 & 55 & 24,3 & 89 & 23,7 \\
\hline
\end{tabular}

\section{Keterangan:}

$\sum \quad$ : Jumlah responden dalam kelompok tersebut

$\% \quad$ : Persentase jumlah responden dalam kelompok tersebut

Secara keseluruhan, perbandingan persentase sikap sangat positif dan positif mahasiswa laki-laki dan perempuan setara. Artinya, jika komposisi jumlah mahasiswa laki-laki dan perempuan berimbang. Jumlah mahasiswa laki-laki yang sangat positif sama dengan jumlah mahasiswa perempuan yang sangat positif. Begitu pula sebaliknya, jumlah mahasiswa lakilaki yang positif sama dengan jumlah mahasiswa perempuan yang positif.

Berdasarkan komposisi jumlah responden yang bersikap sangat positif dan positif, persentase mahasiswa perempuan yang bersikap sangat positif $(77,9 \%)$ lebih tinggi daripada persentase mahasiwa laki-laki yang bersikap sangat positif $(76,2 \%)$. Hal ini menunjukkan bahwa mahasiswa perempuan yang bersikap sangat positif lebih banyak daripada mahasiswa laki-laki yang bersikap sangat positif.

Berbeda dengan sikap, berdasarkan komposisi jumlah responden yang bermotivasi sangat positif dan positif, persentase mahasiswa laki-laki yang bermotivasi sangat positif $(77,1 \%)$ lebih tinggi daripada persentase mahasiwa perempuan yang bermotivasi sangat positif $(75,7 \%)$. Temuan ini menunjukkan bahwa mahasiswa laki-laki yang bermotivasi belajar bahasa Indonesia lebih banyak daripada mahasiswa perempuan.

\section{Sikap Bahasa dan Motivasi Menurut Usia}

Sikap bahasa dan motivasi belajar rupanya memiliki korelasi dengan usia. 
Selama ini dalam kehidupan masyarakat terdapat asumsi bahwa pemuda memiliki sikap bahasa yang lebih negatif daripada orang tua. Namun, bagaimana perbandingan sikap dan motivasi pada kelompok usia muda. Apakah sama seperti saat dibandingkan dengan kelompok usia yang lebih tua? Tabel 7 berikut memerincikan sikap bahasa dan motivasi pada kelompok usia pemuda.

Tabel 7

Rata-Rata Nilai Sikap dan Motivasi Berdasarkan Usia

\begin{tabular}{c|c|c|c}
\hline \multirow{2}{*}{$\begin{array}{c}\text { Usia } \\
\text { (Tahun) }\end{array}$} & \multicolumn{3}{|c}{ Nilai Rata-Rata } \\
\cline { 2 - 4 } & Sikap & Motivasi & Semua \\
\hline 18 & 184,36 & 113,00 & 297,36 \\
\hline 19 & 174,39 & 108,31 & 282,69 \\
\hline 20 & 176,64 & 107,39 & 284,03 \\
\hline 21 & 177,20 & 106,51 & 283,71 \\
\hline 22 & 175,26 & 106,63 & 281,89 \\
\hline 23 & 176,25 & 103,13 & 279,38 \\
\hline$\geq 24$ & 174,04 & 104,74 & 278,78 \\
\hline Jumlah & $\mathbf{1 7 6 , 4 6}$ & $\mathbf{1 0 6 , 8 3}$ & $\mathbf{2 8 3 , 2 9}$ \\
\hline
\end{tabular}

Berdasarkan Tabel 7, dapat diketahui bahwa pada kelompok generasi muda, semakin tinggi usia pemuda, semakin negatif sikap bahasa dan motivasinya. Sebaliknya, semakin muda usia pemuda, semakin positif sikap bahasa dan motivasinya. Temuan ini cukup mengejutkan karena biasanya semakin dewasa seseorang, semakin dewasa pula pola pikir dan sikapnya. Namun, diharapkan grafik sikapnya akan naik lagi pada umur tertentu. Temuan pada Tabel 7 perlu dilihat dan diteliti dengan lebih spesifik dan detail.

\section{Korelasi Sikap Bahasa dan Motivasi dengan Nilai UKBI}

Uji Kemahiran Berbahasa Indonesia (UKBI) merupakan sistem uji yang multiguna. Pemaanfaatannya dalam mengukur kemahiran berbahasa tidak hanya digunakan bagi pelajar dan mahasiswa, tetapi juga bagi penutur bahasa Indonesia dari kalangan professional, bahkan bagi penutur asing. Dalam penggunaan bahasa Indonesia tulis, UKBI mengukur keterampilan aktif reseptif peserta uji dalam kegiatan membaca dan mengukur keterampilan aktif produktif peserta uji dalam kegiatan menulis. Selain menekankan pengukuran terhadap empat keterampilan mikro berbahasa tersebut, UKBI juga mengukur pengetahuan peserta uji dalam penerapan kaidah bahasa Indonesia.

Dari 375 responden yang juga telah mengikuti UKBI, diketahui bahwa rata-rata nilai UKBI responden adalah 521,23 atau pada predikat IV (Madya). Dengan nilai rata-rata setiap seksi adalah 523,67 (Seksi 1), 495,95 (Seksi 2), dan 544,07 (Seksi 3). Adapun nilai terendah dan tertinggi dapat dilihat dalam Tabel 8 berikut ini.

Tabel 8

Nilai Tertinggi dan Terendah UKBI

\begin{tabular}{c|c|c|c|c}
\hline \multirow{2}{*}{ Nilai } & $\begin{array}{c}\text { Seksi } \\
\mathbf{1}\end{array}$ & $\begin{array}{c}\text { Seksi } \\
\mathbf{2}\end{array}$ & $\begin{array}{c}\text { Seksi } \\
\mathbf{3}\end{array}$ & \multirow{2}{*}{ UKBI } \\
\hline Terendah & 335 & 272 & 350 & 365 \\
\hline Tertinggi & 650 & 728 & 710 & 652 \\
\hline
\end{tabular}

Berdasarkan nilai rata-rata UKBI responden, terlihat bahwa nilai Seksi 2: Merespons Kaidah merupakan nilai ratarata terendah, sedangkan nilai Seksi 3: Membaca adalah nilai tertinggi. Hal ini menunjukkan bahwa pemahaman terhadap kaidah bahasa Indonesia masih tergolong sulit bagi mahasiswa. Sebaliknya, membaca menjadi hal yang cukup mudah dibandingkan dengan aspek kemahiran berbahasa yang lain.

Jika nilai UKBI yang diperoleh dihubungkan dengan sikap bahasa dan motivasi belajar, didapatkan hasil sebagaimana terlihat dalam Tabel 9, 10, dan 11 berikut ini.

Tabel 9

Korelasi Sikap dan Nilai UKBI

\begin{tabular}{c|c|c|c|c|c}
\hline \multirow{2}{*}{ Sikap } & \multirow{2}{*}{$\boldsymbol{\Sigma}$} & \multicolumn{4}{|c}{ Rata-Rata Nilai } \\
\cline { 3 - 6 } & Sk. 1 & Sk. 2 & Sk. 3 & UKBI \\
\hline $\mathrm{S}+$ & 277 & 531,99 & 508,72 & 558,25 & 532,99 \\
\hline
\end{tabular}




\begin{tabular}{c|c|c|c|c|c}
\hline+ & 97 & 501,39 & 459,82 & 504,49 & 488,57 \\
\hline $\mathrm{C}-$ & 1 & 410 & 464 & 560 & 478 \\
\hline
\end{tabular}

Tabel 10

Korelasi Motivasi dan Nilai UKBI

\begin{tabular}{c|c|c|c|c|c}
\hline \multirow{2}{*}{$\begin{array}{c}\text { Moti } \\
\text { vasi }\end{array}$} & $\boldsymbol{\Sigma}$ & \multicolumn{4}{|c}{ Rata-Rata Nilai } \\
\cline { 2 - 6 } S + & 286 & 530,51 & 506,05 & 556,16 & 530,91 \\
\hline+ & 89 & 501,68 & 463,49 & 505,23 & 490,13 \\
\hline
\end{tabular}

Tabel 11

Korelasi Sikap, Motivasi, dan Nilai UKBI

\begin{tabular}{c|c|c|c|c|c}
\hline \multirow{2}{*}{} & \multirow{2}{*}{$\boldsymbol{\Sigma}$} & \multicolumn{4}{|c}{ Rata-Rata Nilai } \\
\cline { 3 - 6 } & Sk. 1 & Sk. 2 & Sk. 3 & UKBI \\
\hline $\begin{array}{c}\text { S } \\
+\end{array}$ & 289 & 530,20 & 504,95 & 555,99 & 530 \\
\hline+ & 85 & 503,17 & 465,72 & 504,59 & 491 \\
\hline C - & 1 & 410 & 464 & 560 & 478 \\
\hline
\end{tabular}

Keterangan:

$\sum \quad$ : Jumlah responden dalam kelompok tersebut

Sk. 1 : Seksi 1 UKBI (Mendengarkan)

Sk. 2 : Seksi 2 UKBI (Merespons Kaidah)

Sk. 3 : Seksi 3 UKBI (Membaca)

$\mathrm{S}+\quad$ : Sangat positif

$+\quad$ : Positif

C - : Cukup negatif

Berdasarkan Tabel 9, terlihat bahwa semakin positif sikap seseorang terhadap bahasa Indonesia, semakin tinggi pula nilai UKBI-nya. Rata-rata skor UKBI kelompok sikap sangat positif adalah 532,99, sedangkan ratarata skor UKBI kelompok sikap positif hanya 488,57, dan rata-rata skor UKBI kelompok sikap cukup negatif hanya 478.

Sama halnya dengan sikap, motivasi dan nilai UKBI juga berkorelasi positif. Semakin tinggi motivasi seseorang dalam belajar bahasa Indonesia, semakin tinggi pula nilai UKBI-nya. Temuan ini kontras terlihat dalam semua nilai rata-rata setiap seksi dan nilai akhir UKBI. Skor Seksi 3 Membaca kelompok motivasi tinggi adalah 556,16, sedangkan motivasi di bawahnya skor membaca yang diperoleh hanya 505,23, padahal Seksi 3 dan Seksi 1 tidak berhubungan langsung dengan motivasi dan pembelajaran bahasa Indonesia. Seksi 3 Membaca dan Seksi 1 Mendengar tidak diperoleh semata-mata dari belajar Bahasa Indonesia secara formal, tetapi cenderung dihasilkan dari kebiasaan penggunaan bahasa Indonesia sehari-hari. Berbeda dengan nilai Seksi 2 Merespons Kaidah yang umumnya cenderung dihasilkan dari pengetahuan yang diperoleh peuji saat belajar Bahasa Indonesia secara formal, baik di sekolah maupun di kampus.

Temuan tersebut semakin jelas terlihat saat nilai sikap dan motivasi digabungkan dan disandingkan dengan nilai UKBI. Keduanya berkorelasi positif.

\section{Gambaran Sikap Bahasa dan Motivasi Belajar Mahasiswa}

Pada bagian ini dipaparkan beberapa kondisi sikap bahasa dan motivasi belajar mahasiswa berdasarkan jawaban responden.

\section{Fungsi Bahasa Indonesia}

Seluruh responden menyatakan bahwa bahasa Indonesia merupakan bahasa yang komunikatif dan memudahkan responden dalam menambah informasi dan pengetahuan. Namun, sebagian kecil responden meragukan kemampuan bahasa Indonesia dalam menyerap informasi, ilmu pengetahuan, dan teknologi. Mereka juga meragukan kemampuan bahasa Indonesia dalam mempercepat upaya pencerdasan bangsa dan bermanfaat dalam memperluas pergaulan. Selain itu, beberapa responden beranggapan bahwa bahasa Indonesia itu tidak efisien, tidak mencerminkan kemodernan, dan tidak mencerminkan intelektualitas.

Pengakuan mahasiswa bahwa bahasa Indonesia komunikatif dan memudahkan dalam menambah 
informasi dan pengetahuan merupakan kenyataan yang patut kita syukuri. Namun, patut juga dicurigai bahwa anggapan memudahkan dalam menambah informasi dan pengetahuan disebabkan oleh kurangnya penguasaan mahasiswa terhadap bahasa asing yang mungkin saja harus mereka hadapi saat membaca buku teks di kampus. Oleh karena itu, saat kedua bahasa itu disandingkan, bahasa Indonesia dianggap lebih memudahkan mahasiswa dalam menyerap informasi dan pengetahuan.

Anggapan bahwa bahasa Indonesia tidak efisien, tidak mencerminkan kemodernan, dan tidak mencerminkan intelektualitas adalah sebuah kenyataan dalam masyarakat Indonesia pada umumnya. Hal ini tecermin dalam penggunaan bahasa asing di ranah publik, media publik, dan media luar ruang kita. Salah satu alasan masyarakat lebih memilih bahasa asing, khususnya bahasa Inggris, adalah alasan prestise agar lebih terlihat keren, modern, dan intelek.

Pandangan seperti ini harus diubah. Memang tidak mudah dan tidak dapat cepat, perlu waktu lama untuk mengubah pola pikir masyarakat. Padahal, pada kenyataannya bahasa Indonesia pun mampu mencerminkan kemodernan dan intelektualitas. Orang luar saja berlomba mempelajari bahasa Indonesia, tetapi justru kita sendiri yang tidak bangga dan tidak acuh terhadap bahasa kita.

\section{Penggunaan Bahasa}

Berdasarkan pernyataan nomor 5 , yaitu seringnya menggunakan bahasa Indonesia, mahasiswa menyatakan bahwa mereka lebih sering menggunakan bahasa Indonesia, terutama saat bertelepon, SMS, maupun chatting. Namun, sayangnya, mahasiswa lebih sering menggunakan ungkapan, kata, atau istilah dalam bahasa asing (pernyataan nomor 5).

Fenomena tersebut disebabkan ketidaktahuan mereka terhadap bahasa Indonesia yang juga telah memiliki ungkapan, kata, atau istilah yang mampu mengungkapkan konsep yang ada dalam kehidupan, khususnya dalam ilmu pengetahuan. Pemerintah telah mengupayakan pengayaan kosakata baik itu dari bahasa daerah maupun pengindonesiaan istilah asing yang dapat diakses melalui laman Senarai Pengindonesiaan Istilah Asing. Kekayaan kosakata bahasa Indonesia juga terkumpul di Kamus Besar Bahasa Indonesia, baik dalam versi cetak, daring, maupun aplikasi luring di ponsel. Media yang sudah ada itu rupanya belum termanfaatkan secara maksimal oleh masyarakat.

Berkaitan dengan penggunaannya dalam komunikasi di kampus, mahasiswa lebih banyak menggunakan bahasa daerah saat berbicara dengan teman. Namun, saat berbicara dengan dosen, mahasiswa lebih banyak menggunakan bahasa Indonesia. Penggunaan bahasa daerah menunjukkan ada kedekatan dan keakraban antarpenutur. Sebaliknya, penggunaan bahasa Indonesia menunjukkan ada jarak sosial antarpenutur. Situasi percakapan juga turut memengaruhi penggunaan bahasanya.

Saat di rumah, sebagian besar mahasiswa menggunakan bahasa ibu (dalam hal ini bahasa daerah) untuk berkomunikasi dengan anggota keluarga lainnya. Kenyataan ini cukup menggembirakan karena bahasa daerah, khususnya bahasa Melayu Bangka, masih digunakan dalam kehidupan sehari-hari sehingga dapat dikatakan jauh dari ancaman kepunahan.

\section{Pemanfaatan Bahasa}


Semua responden sepakat bahwa mempelajari bahasa Indonesia memiliki banyak manfaat. Hanya sebagian kecil $(4,5 \%)$ yang menganggap bahwa penguasaan bahasa Indonesia tidak mempermudah orang dalam mendapat pekerjaan.

Responden juga sepakat bahwa orang asing yang akan bekerja atau belajar di Indonesia harus mampu berbahasa Indonesia. Hal ini dapat dibuktikan melalui skor UKBI sebagaimana saat orang Indonesia akan bekerja atau belajar di luar negeri juga harus memiliki sertifikat tes kemahiran bahasa negara tujuan. Namun, kewajiban berbahasa Indonesia ini belum diberlakukan secara ketat di Indonesia, baik dalam hal bekerja maupun belajar.

Sebagaimana tertuang dalam Pasal 26, Perpres RI Nomor 20 Tahun 2018 yang menyatakan bahwa setiap pemberi kerja TKA (tenaga kerja asing) wajib memfasilitasi pendidikan dan pelatihan bahasa Indonesia kepada TKA. Peraturan tersebut sekaligus menegaskan bahwa tidak ada kewajiban bagi TKA yang bekerja di Indonesia mengerti atau menguasai bahasa Indonesia. Kewajibannya hanya memfasilitasi pendidikan dan pelatihan berbahasa Indonesia. Melalui peraturan ini, pemerintah ingin memperpendek jalur birokrasi dan pengurusan dokumen TKA serta menyingkronkan peraturan menteri yang satu dengan menteri yang lain yang banyak bertabrakan. Bagi pengusaha, peraturan ini diterima dengan baik karena mempermudah pengurusan izin TKA. Namun, bagi pengembangan bahasa Indonesia, hal ini merupakan suatu kemunduran usaha.

Selanjutnya, sebagian besar responden $(89,87 \%)$ juga menyatakan setuju jika bahasa Indonesia dijadikan salah satu syarat pengangkatan pejabat. Gagasan ini menunjukkan keinginan mahasiswa agar para pejabat, baik itu di daerah maupun di pusat, dapat menggunakan bahasa Indonesia dengan lebih baik dan lebih santun lagi.

\section{Kebanggaan Berbahasa}

Semua responden sepakat bahwa semua orang Indonesia harus bangga berbahasa Indonesia dan cinta bahasa Indonesia untuk menunjukkan bahwa kita orang Indonesia. Sikap bangga dan cinta tersebut juga tecermin melalui jawaban pernyataan nomor 21 , yaitu bahasa Indonesia harus harus lebih diutamakan daripada bahasa lain dan pernyataan nomor 41 , yaitu kita harus bangga dengan bahasa kita sendiri, yaitu bahasa Indonesia.

Selain itu, dari pernyataan ini terlihat komitmen mahasiswa untuk berusaha menggunakan bahasa Indonesia dengan lebih baik lagi. Komitmen ini dilaksanakan dengan cara berusaha: menulis sesuai kaidah bahasa Indonesia yang baik dan benar (pernyataan nomor 37), mengacu pada Kamus Besar Bahasa Indonesia (pernyataan nomor 38), berusaha menguasai kosakata dan ejaan bahasa Indonesia yang sudah dibakukan (pernyataan nomor 39), berusaha berbicara bahasa Indonesia dengan baik dan benar (pernyataan nomor 40), dan berusaha meningkatkan kemampuan berbahasa Indonesia (pernyataan nomor 34).

\section{Pewarisan Bahasa}

Semua responden sepakat bahwa setiap orang Indonesia harus mengupayakan agar anaknya mampu berbahasa Indonesia. Komitmen ini semoga juga dapat diterapkan pada keluarga mereka nantinya. Saat ini pewarisan bahasa Indonesia rupanya mulai pudar terutama di kota-kota besar. Banyak keluarga mengajari dan menggunakan bahasa Inggris kepada anak-anaknya di rumah. Perilaku ini dapat menjadi ancaman bagi pelestarian bahasa Indonesia. 
Kandai Vol. 17, No. 1, Mei 2021; 14-29 


\section{Pandangan terhadap Bahasa}

Berkaitan dengan perkembangan bahasa Indonesia, sebagian besar $(52,3 \%)$ responden sepakat bahwa bahasa Indonesia harus menjadi bahasa internasional dan percaya bahwa bahasa Indonesia suatu saat akan memiliki peranan penting dalam percaturan dunia. Optimisme ini semoga dapat terus terjaga dan terpelihara agar dukungan masyarakat terhadap penginternasionalan bahasa Indonesia terus bertumbuh dan cita-cita tersebut terwujud.

Namun, sayangnya, sebagian responden $(40,53 \%)$ merasa lebih percaya diri saat menggunakan bahasa Inggris. Pandangan seperti ini masih sulit sekali diubah di masyarakat kita. Bahasa Inggris telanjur memiliki prestise yang jauh lebih tinggi dibanding bahasa Indonesia. Tidak dapat dimungkiri bahwa bahasa Inggris merupakan bahasa internasional yang juga harus dikuasai agar kita dapat berinteraksi dengan warga dunia. Sebagai warga masyarakat global, kita tidak boleh anti terhadap bahasa Inggris, tetapi seharusnya kita tetap mengutamakan bahasa Indonesia sebagai bahasa negara di atas bahasa lainnya.

\section{Motivasi Belajar Bahasa}

Sebagian besar responden $(83,47 \%)$ menyatakan bahwa mereka suka belajar bahasa Indonesia dan merasa penting untuk mempelajarinya. Mereka juga menyatakan bahwa mempelajari bahasa Indonesia dapat membantu memahami kehidupan sosial orang Indonesia, memahami kebudayaan lain di Nusantara, memahami karakter orang Indonesia, memahami berita-berita di media massa dengan lebih baik, memungkinkan mereka bertemu, berbicara, dan bercakap-cakap dengan orang Indonesia berlatar belakang berbagai suku.

Namun, sebagian kecil $(13,33 \%)$ responden berpendapat bahwa belajar bahasa Indonesia membosankan dan sebagian responden melupakan semua materi kuliah karena tidak suka bahasa Indonesia. Bahkan, 3,2\% responden menyatakan bahwa mereka benci belajar bahasa Indonesia. Pandangan ini memang tidak semata-mata karena faktor bahasa Indonesianya saja. Ketidaksukaan ini dapat juga karena pengajarnya yang kurang menarik sehingga mahasiswa kurang berminat dalam belajar.

\section{PENUTUP}

Berdasarkan penelitian disimpulkan bahwa mahasiswa Pulau Bangka lebih cenderung bersikap positif terhadap bahasa Indonesia. Hal ini dapat berpengaruh baik terhadap sikap masyarakat yang lain terhadap penggunaan bahasa Indonesia. Begitu pula dengan motivasi belajar mahasiswa Pulau Bangka terhadap bahasa Indonesia. Meskipun (sebaiknya disebutkan angkanya) yang bersikap negatif, jumlahnya tidak terlalu mengkhawatirkan. Penelitian ini juga menemukan bahwa pada kelompok generasi muda, semakin tinggi usianya semakin negatif sikap bahasa dan motivasi mereka. Sebaliknya, semakin muda usianya, semakin positif sikap bahasa dan motivasi mereka.

Berdasarkan rata-rata nilai UKBI responden, terlihat bahwa nilai Seksi 2: Merespons Kaidah merupakan nilai ratarata terendah $(495,95)$, sedangkan nilai Seksi 3: Membaca adalah nilai tertinggi $(544,34)$. Temuan ini menunjukkan bahwa pemahaman terhadap kaidah bahasa Indonesia masih tergolong sulit bagi mahasiswa. 
Temuan lain dari penelitian ini adalah semakin positif sikap seseorang terhadap bahasa Indonesia, semakin tinggi pula nilai UKBI-nya. Sama halnya dengan sikap, motivasi dan nilai UKBI juga berkorelasi positif. Semakin tinggi motivasi seseorang dalam belajar bahasa Indonesia, semakin tinggi pula nilai UKBI-nya. Hal ini kontras terlihat dalam semua nilai rata-rata setiap seksi dan nilai akhir UKBI.

Secara umum, gambaran sikap bahasa dan motivasi mahasiswa Pulau Bangka cukup baik. Sikap dan motivasi ini terlihat dari pandangan mereka terhadap fungsi bahasa Indonesia, penggunaan bahasa Indonesia dan asing, pemanfaatan bahasa, kebanggaan berbahasa, pewarisan bahasa, serta pandangan terhadap bahasa Indonesia, daerah, dan asing.

\section{DAFTAR PUSTAKA}

Andarwulan, T., \& Aswadi. (2018). Menilik sikap bahasa mahasiswa Universitas Brawijaya: Upaya peneguhan bahasa Indonesia menuju internasionalisasi bahasa. Waskita: Jurnal Pendidikan Nilai dan Pembangunan Karakter, 2(2), $\quad$ 61--70. doi:https://doi.org/10.21776/ub.w askita:jurnalpendidikannilaidanpe mbangunankarakter.2018.002.02. 6

Chaer, A., \& Agustina, L. (2010). Sosiolinguistik: Perkenalan awal. Jakarta: Rineka Cipta.

Garvin, P., \& Mathiot, M. (1968). The urbanization of Guarni language, Problem in language and culture. In J. Fishman, Reading in tes sosiology of language. Mounton, Paris: The Hague.

Gunarwan, A. (1983). Reaksi Subjektif terhadap BIB dan NB: Sebuah pengkajian sikap bahasa.
Kongres Bahasa Indonesia IV (p. 1). Jakarta: Pusat Bahasa.

Kridalaksana, H. (2001). Kamus linguistik. Jakarta: Gramedia Pustaka Utama.

Mansyur, U. (2018). Sikap bahasa dan pembelajaran bahasa Indonesia di perguruan tinggi. The 1th International Conference of Asosiasi Linguistik Terapan Indonesia (ICon ALTI) (pp. 1--8). Makassar: Universitas Muslim Indonesia.

Mukhamdanah. (2007). Pemertahanan dan sikap bahasa di kalangan mahasiswa warga universitas Sumatra Utara. Tesis . Medan: Fakultas Sastra Universitas Sumatra Utara.

Pateda, M. (1987). Sosiolinguistik. Bandung: Angkasa.

Penyusun, T. (2018). Kamus besar bBahasa Indonesia edisi $V$. Jakarta: Badan Pengembangan dan Pembinaan Bahasa, Kementerian Pendidikan dan Kebudayaan Republik Indonesia.

Saussure, F. d. (1966). A Course in General Linguistics. New York: McGraw-Hill.

Sobara, I., \& Ardiyani, D. K. (2013, Februari). Sikap bahasa mahasiswa laki-laki dan perempuan di jurusan Sastra Jerman Universitas Negeri Malang. Bahasa dan Seni: Jurnal Bahasa, Sastra, Seni, dan Pengajarannya, 41(1), 93--105. Retrieved from http://journal2.um.ac.id/index.ph $\mathrm{p} / \mathrm{jbs} / \mathrm{index}$

Sugiyono, \& Sasangka, S. S. (2011). Sikap masyarakat Indonesia terhadap Bahasanya. Yogyakarta: Elmatera Publishing. Suhardi, B. (1996). Sikap bahasa. Depok: Fakultas Sastra, Universitas Indonesia. 
Sukyadi, D. (2013, Oktober). Dampak pemikiran Saussure bagi perkembangan linguistik dan disiplin ilmu lainnya. Parole, 3(2), 1--19.

Sumarsono, \& Partana, P. (2002). Sosiolinguistik. Yogyakarta: Sabda.
Werdiningsih, E. (2016). Menumbuhkan rasa bangga generasi muda terhadap bahasa Indonesia sebagai bahasa nasional dan internasional. Likhitaprajna: Jurnal Ilmiah Fakultas Keguruan dan Ilmu Pendidikan, 18(2), 20-25. Retrieved from http://likhitapradnya.wisnuwardh ana.ac.id/index.php/likhitapradny a/article/view/55 